\title{
Macroeconomic performance amid global crisis
}

\section{Yiping Huang, Ken Peng and Minggao Shen}

\section{The turnaround of macroeconomic conditions}

The Chinese economy took another drastic turn at the beginning of 2009 . According to a survey by the China Center for Economic Research, the average forecast of gross domestic product (GDP) growth for the second quarter of 2009 by 20 international and domestic institutions went up to 7 per cent from the real performance of 6.1 per cent during the first quarter. This confirms broad confidence in the belief that the Chinese economy has probably already bottomed out.

This improvement in sentiment is attributable mainly to better-thanexpected economic data in early 2009 - especially stabilisation of industrial production and a rebound in fixed-asset investment. In particular, the purchasing managers' index (PMI) of the manufacturing sector rose from 36 in November 2008 to about 53 in April and May 2009. This implied that managers' expectations shifted from sharp contraction to steady expansion.

The quick turnaround probably surprised most capital market investors and financial industry analysts. We, however, have been of the view that China should be able to maintain relatively strong growth in 2009 and 2010, relying on the government's strong capability for mobilising resources. Excessive pessimism among some investors and analysts earlier was, in our view, caused by two key factors: misinterpretation of economic trends and underestimation of the government's capability.

First, economic data weakened sharply during the fourth quarter of 2008. The growth of industrial production decelerated from above 15 per cent early that year to about 3-5 per cent at the end of 2008. In particular, the growth in power generation shifted from above 10 per cent to -9 per cent. Demand for key commodities, such as steel, copper and aluminium, also collapsed. These changes led to widespread worries that the Chinese economy was falling off a cliff. 
In the meantime, however, data on underlying demand in the economy were stronger. Growth in retail sales - a key indicator of consumer spending - continued to grow strongly. Net exports also continued to surge, as imports declined much faster than exports. The real growth of fixed-asset investment moderated - from 20-25 per cent in the year to the start of 2008, to 10-15 per cent in the year to the end of the year-caused mainly by a collapse in real estate investment.

The inconsistency between rapidly weakening production-based data and relatively resilient expenditure data could be explained by inventory adjustment. De-stocking is a common phenomenon during economic downturns. In the years preceding the recent downturn, inventories accumulated drastically because of a long period of economic boom and commodity price inflation. These trends, however, reversed from mid2008 as the global economy fell into recession while commodity markets tanked. This led to a massive reduction of inventories.

This implied, however, that the weakening of production activities was exaggerated compared with moderation in underlying economic demand. Meanwhile, it also suggested that once the de-stocking process ended, industrial production could stabilise, unless the slowdown in economic demand accelerated. In particular, the potential pick-up of underlying demand could lead to re-stocking and faster acceleration of production than underlying demand.

Second, many investors and analysts were sceptical about the government's ability to support growth. One representative view was that, after 30 years of economic reform, China was already a 'typical capitalist economy'. With limited policy influence, a typical capitalist economy would likely be subject to violent economic cycles.

This view reflected, however, a significant underestimation of the government's ability to influence economic activities in China. Truethe economy has become more market oriented in past decades, but the government managed to deliver steady economic growth during the East Asian financial crisis. Compared with 10 years ago, the government's ability to mobilise resources has actually strengthened, not weakened.

Ten years ago, government revenue accounted for 11 per cent of GDP. Today, its share is already 21 per cent. Ten years ago, the average ratio of non-performing loans of the Chinese banks was close to 40 per cent. Today, not only is this ratio about only 7 per cent, the banks are all well 
capitalised and quite liquid. Ten years ago, state-owned enterprises (SOEs) as a whole made net losses. Today, they are generally profitable. Clearly, the government's ability to influence economic activities goes well beyond direct budget spending.

The evolution of these two factors contributed to the turnaround of China's macroeconomic conditions in early 2008. A recent increase in GDP forecasts reflected improvement in the general sentiment, especially in international capital markets. Chinese economists as a whole were never as pessimistic as their counterparts overseas.

There is now a consensus that the growth in the Chinese economy has already passed its lowest point. Some believe that China will lead the world out of recession this time around. However important issues remain. Is China's growth recovery sustainable? Will the governmentsupported cyclical rebound enhance or hinder structural transition of the Chinese economy? What other policy options are available to improve the sustainability of strong growth? These are some of the key questions we address in this chapter.

\section{An update of macroeconomic performance}

Only a year ago, the Chinese authorities were still busy fighting inflation. In February 2008, the increase in the consumer price index (CPI) reached a cyclical high of 8.7 per cent, led by above- 20 per cent inflation in the price of food. The People's Bank of China (PBOC) adopted various measures to tighten monetary policy, including raising policy rates, increasing reserve requirements and appreciating the currency.

From mid-2008, however, macroeconomic conditions turned down. GDP growth decelerated from 9 per cent in the year to the first quarter of 2008 to 6.7 per cent in the year to the fourth quarter. The slowdown of the economy was partly attributable to the tightening policies implemented earlier; but it was caused mainly by weakening of the global economy following the US sub-prime crisis.

This development abruptly ended the first phase of the debate about decoupling the Chinese and US economies. The decoupling thesis was, at the minimum, unrealistic given China's open-door policy and integration with the world economy during the past 30 years. The current US financial crisis affected the Chinese economy mainly through the following three 
channels: weakening of exports, reversal of capital flows and loss of investor confidence.

Responding to the changing macroeconomic conditions, the PBOC quickly started to loosen monetary policies, with the first rate cut in September 2008. Currency appreciation also came to an abrupt halt during the second half of the year. Most importantly, the PBOC's credit policy shifted from strict control of loan growth in early 2008 to effective encouragement of loan extension in early 2009.

Export growth collapsed from 20-30 per cent on a year-to-year basis a year ago to about -20 per cent in recent months (Figure 7.1). Recently, there have been signs of stabilising consumer confidence and financial conditions in the United States. Despite the initial improvement, however, both indicators remain at extremely low levels and it will be some time before they can translate into a recovery of China's exports. Port traffic in May still showed no meaningful improvement from April-and still weakening shipping rates echoed this disappointing trend.

China's exports are therefore not likely to recover significantly any time soon. This is determined fundamentally by the dim outlook for the major industrial economies, which account for more than 60 per cent of China's export market. Even the more optimistic views suggest stabilisation of the US economy about the turn of the year, with recovery of the European and Japanese economies lagging that of the United States.

Meanwhile, the steady recovery of Chinese investment paints a more upbeat picture for imports into China, especially imports of investment goods. The recent rally in global dry-bulk freight rates shows a greater increase for rates bound for China and Hong Kong than elsewhere in May compared with April. For example, routes such as Singapore-China and South Korea-China have shown a near-50 per cent rebound since the low in mid-April, while those to Japan and the United States have risen 10-15 per cent from their more recent lows.

Commodity prices picked up significantly in May (Figure 7.2). Crude oil prices rose to around $\$ 70$ a barrel, compared with the recent low of $\$ 32$ a barrel. Assuming stable import volumes, petroleum and related products could add more than $\$ 1$ billion a month to China's import bill. Other commodity prices have also seen varying degrees of rebound-evident in the Commodity Research Bureau (CRB) industrial price index. 
Figure 7.1 Chinese export growth and US financial conditions index (per cent year on year, index)

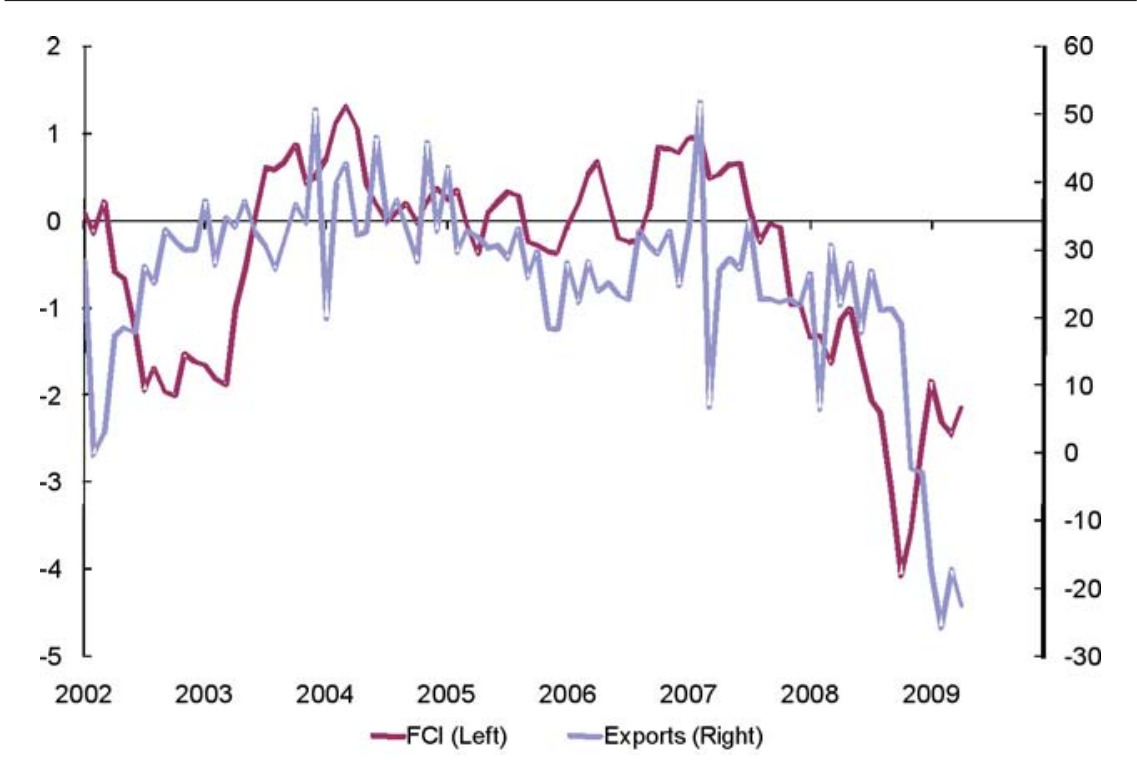

Source: Citi Investment Research and Analysis.

Figure 7.2 CRB industrial commodity prices and crude oil price (index, \$/barrel)

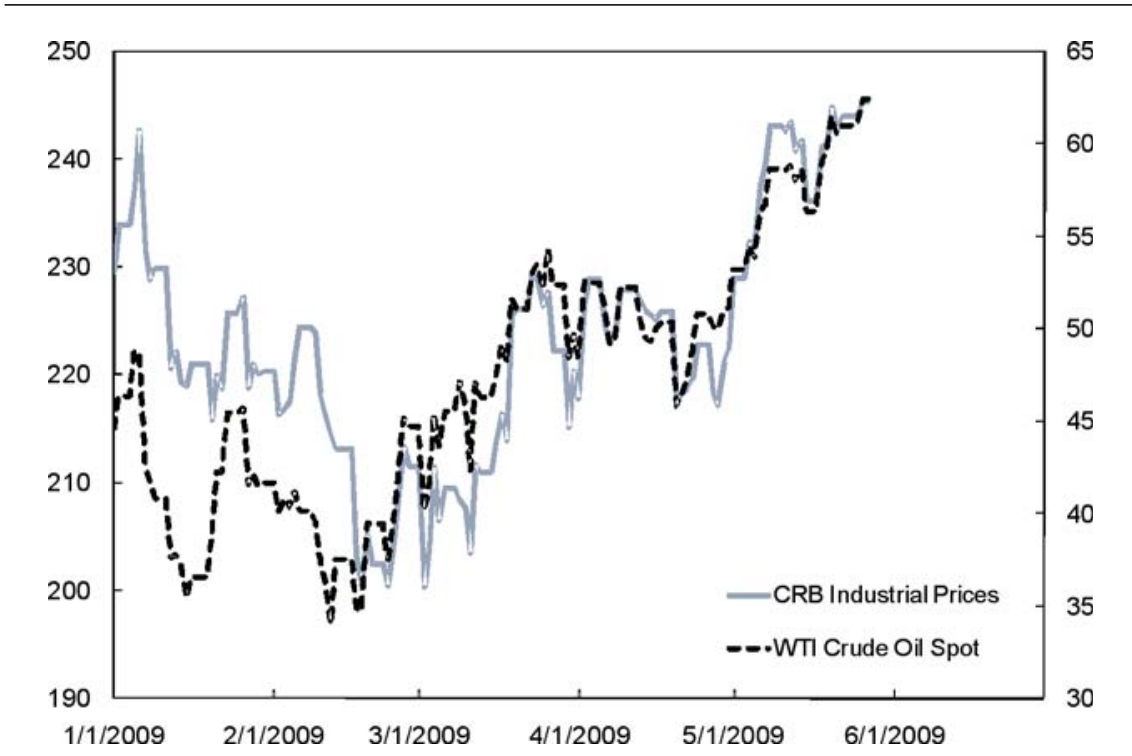

Source: Citi Investment Research and Analysis. 
The faster recovery of imports than of exports suggests that the trade surplus and the current account surplus could shrink further. This would present a greater drag on GDP growth in the coming quarters. During the first quarter, the nominal trade surplus was greater than a year ago; but, removing price changes that penalised imports much more than exports, the surplus was really $\$ 7$ billion short. This produced a 0.2 percentage point drag on GDP growth in that quarter.

An extended weakness in exports and the surplus would be an additional burden on fiscal expansion to protect growth, which could worsen structural imbalances. Given this backdrop, foreign exchange policy is likely to remain unchanged until exports return to growth and the surplus stabilises.

Recent calls for internationalisation of the Chinese yuan will occur only at a gradual pace, with little meaningful impact on transaction volume or currency value in the coming year; the authorities made this clear recently through both word and deed. The State Council said it would keep the yuan stable, boost credit finance and tackle slowing external demandthe biggest challenge to the economy. This explains why Chinese yuan fixing has bucked the falling US dollar recently and weakened against the dollar.

With exports in the gutter, it is difficult for production to provide an extra lift to growth in the near term (Figure 7.3). The recent return of the PMI to above 50 is consistent with modest production growth going forward. The below-40 reading in November 2008 - similar to the levels in the United States and Europe during the same period - was obviously an overshooting.

The government's stimulus policies, meanwhile, could brighten the outlook for production. So far, however, firms are still not expanding, even though the worst of the de-stocking has passed. Stimulus projects are still in their early stages, which could be helping digest inventories but is yielding little boost to new production. 
Figure 7.3 Industrial production and purchasing managers' index (per cent year-on-year)

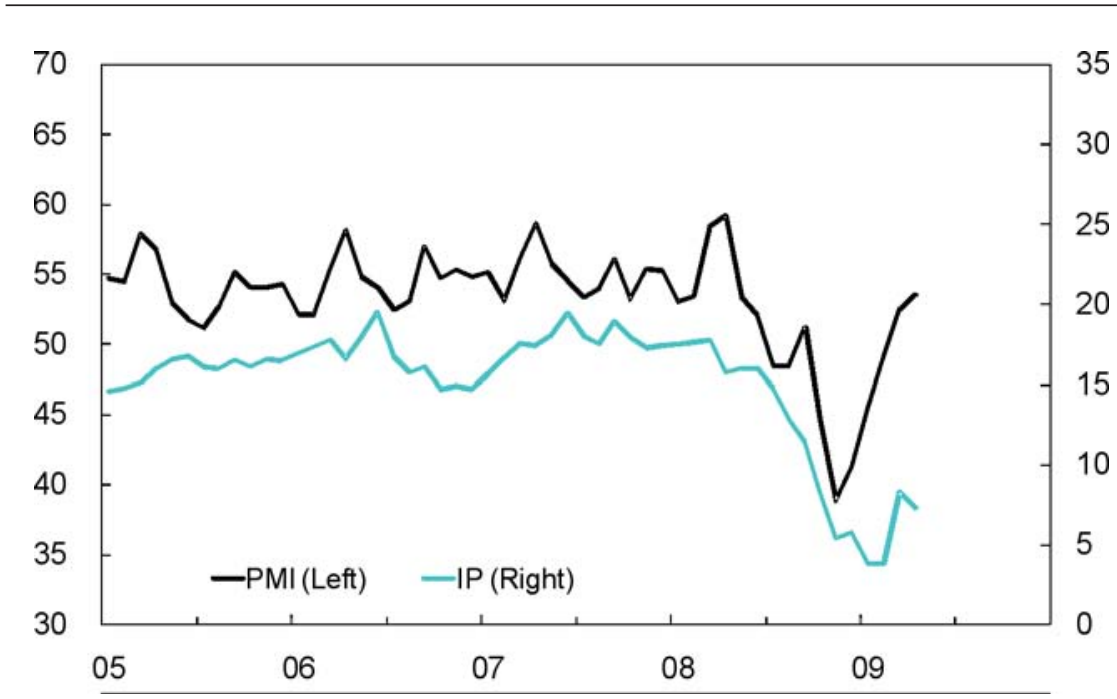

Sources: National Bureau of Statistics and Citi Investment Research and Analysis.

Going forward, investment growth could be slower than what was achieved during the first months of the year. The value of land and used facilities and equipment is included in fixed-asset investment (FAI). These values take a significant share of the total investment (as much as onethird for some projects) and are generally accounted for in lump sums at the beginning of the project. In January-April, the number of new projects totalled more than 86 000, worth RMB3.7 trillion-up 45 per cent and 91 per cent year-on-year, respectively. These projects will take several years to complete, but the land involved is already accounted for and naturally frontloads growth. As a result, FAI growth should start to decelerate soon.

The beginning of construction will probably draw mostly on the inventory of suppliers. This has probably widened the gap between industrial production and FAI growth. Going forward, however, greater investment demand will need to come from current production.

Many observers are puzzled by the gap between tepid levels of power generation and improving economic growth prospects. Indeed, the first four months of 2009 saw FAI increase 30.5 per cent while industrial production grew 5.5 per cent-all accompanying a 3.8 per cent drop in power output. 
The power gap can be attributed to several factors, including greater declines in heavy-industry output such as metals, export weakness and the aforementioned land component of investment. Ultimately, however, the gap will narrow, not only via slower investment growth but by a pickup in electricity production.

Steel output fell 5 per cent year-on-year in April, while non-ferrous metals output declined by 8.6 per cent (Figure 7.4). This highlights the sharp declines in heavy-industry output. Heavy industry accounts for 70 per cent of total industrial production - up from 60 per cent in 1998. It has outgrown light industry by 3 percentage points on average in the past 10 years. From July 2008 through to April this year, heavy-industry growth plummeted by 12 points, while light-industry growth fell by 6 percentage points (Figure 7.5). This steep fall in heavy-industry production contributed to the sharp decline in power consumption.

While export business is likely to remain weak for some time, investment should start to have an impact. Especially encouraging is the stabilisation of residential investment (Figure 7.6).

\section{Figure 7.4 Growth of metal production} (per cent year-on-year)

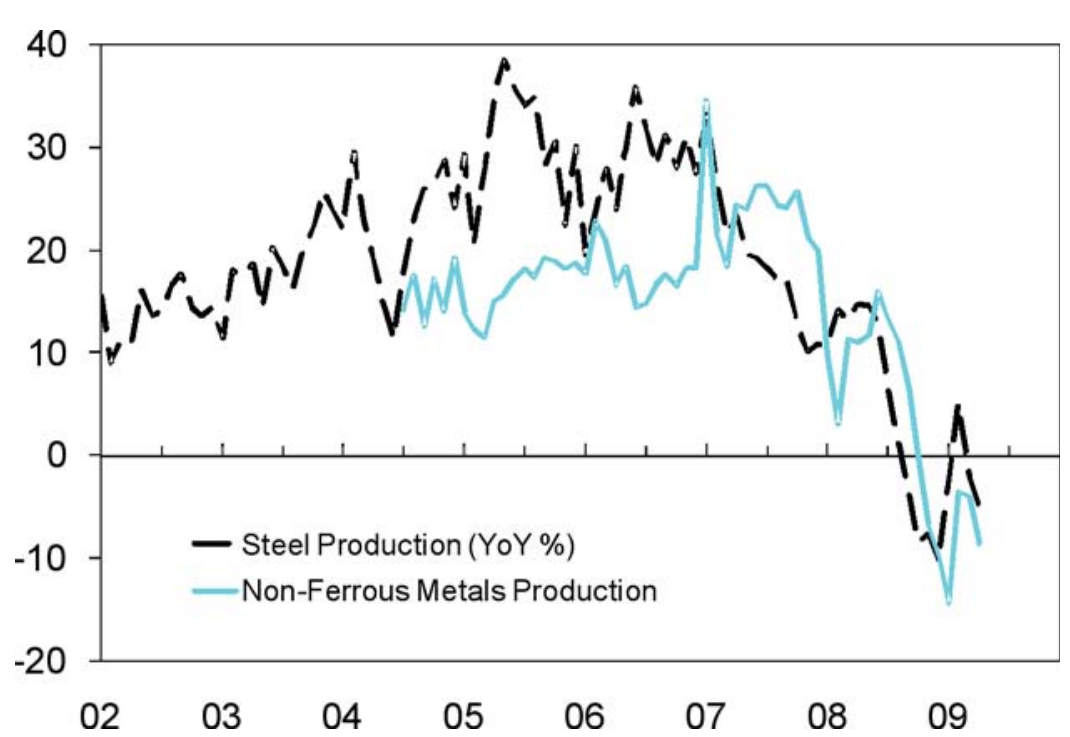

Source: China Steel and Non-Ferrous Metal Industry Association. 
Figure 7.5 Growth of industrial production: heavy versus light industry (per cent year-on-year)

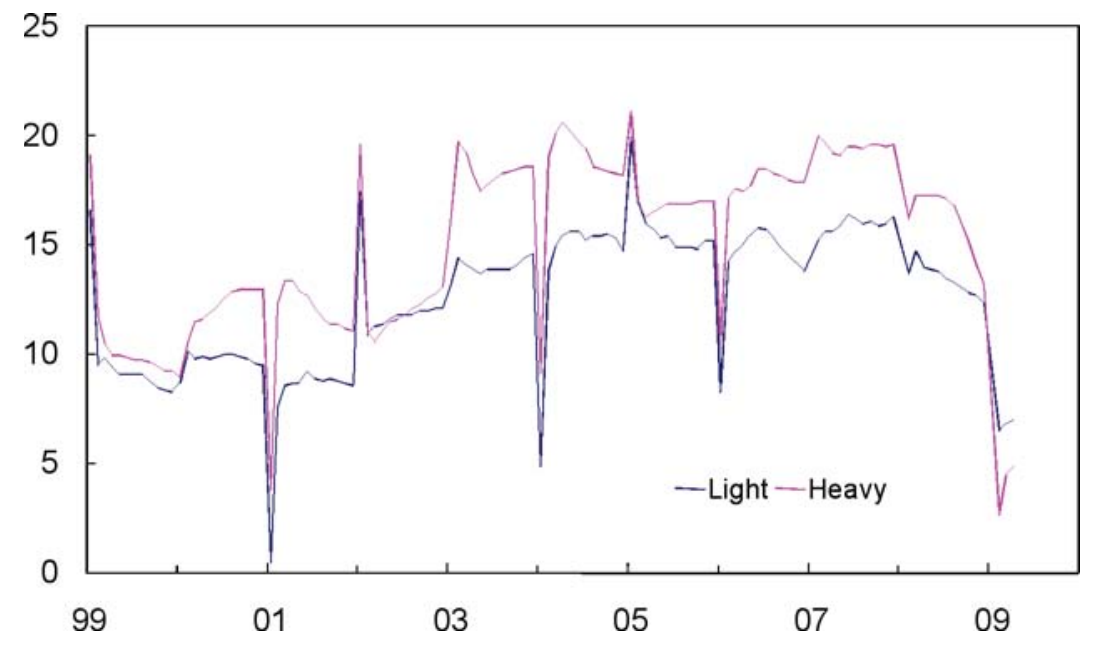

Source: National Bureau of Statistics.

Figure 7.6 Growth of fixed-asset investment: state-owned enterprises, residential and other

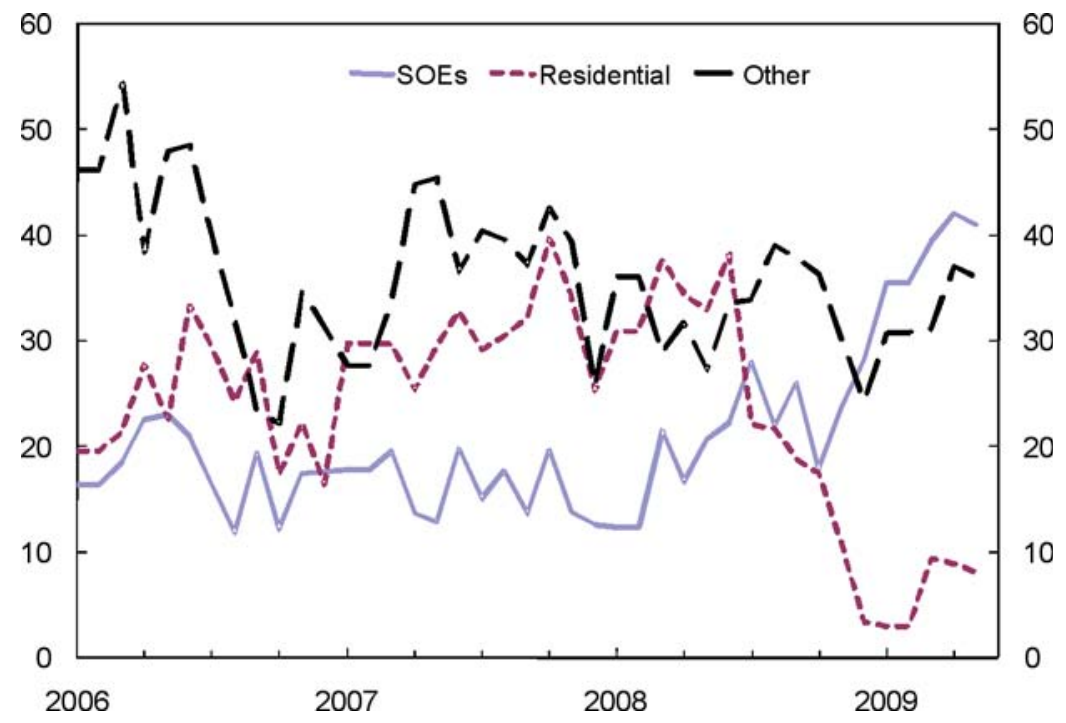

Source: CEIC Data Company. 
Figure 7.7 Growth of power generation and industrial production (per cent year-on-year)

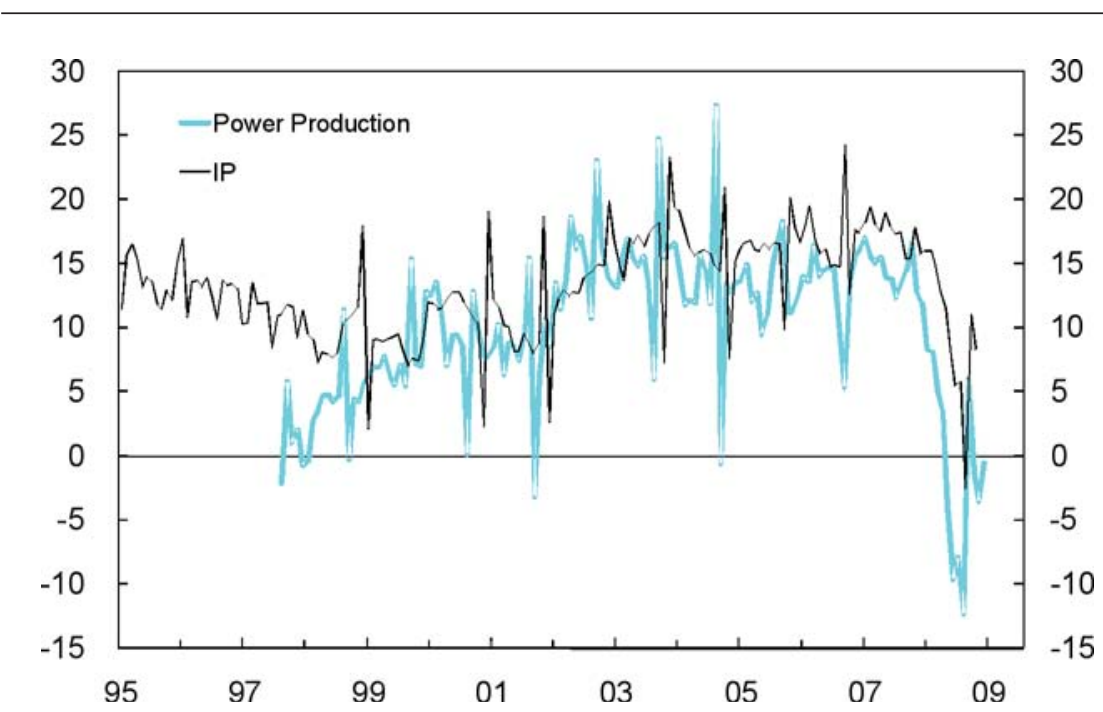

Sources: National Bureau of Statistics and National Power Distribution Center.

The recent sales boom in the property sector - likely to be short-livedhas not alleviated developers' financial pressures or greatly reduced the likelihood of major bankruptcy events. Recent successful land auctions suggest private investment in housing could also resume later this year. In addition, the government's low-cost housing projects have already begun and should add to demand for metals and other heavy industrial products in the second half of the year. All these are factors that should help narrow the power gap (Figure 7.7).

Given the general outlook for the economy, the current risks of deflation and inflation are probably becoming more balanced. The base effect will keep the year-on-year CPI headline negative for several more months, but the monthly changes have already returned to more normal seasonal patterns (Figure 7.8). Especially for the non-food CPI, the April reading of 0.1 per cent month-on-month was the first monthly increase since October 2008. Sharp deflationary pressures are probably behind us, along with severe de-stocking and housing price declines. 


\section{Figure 7.8 Headline CPI, 2007, 2008 and 2009}

(per cent month-on-month)

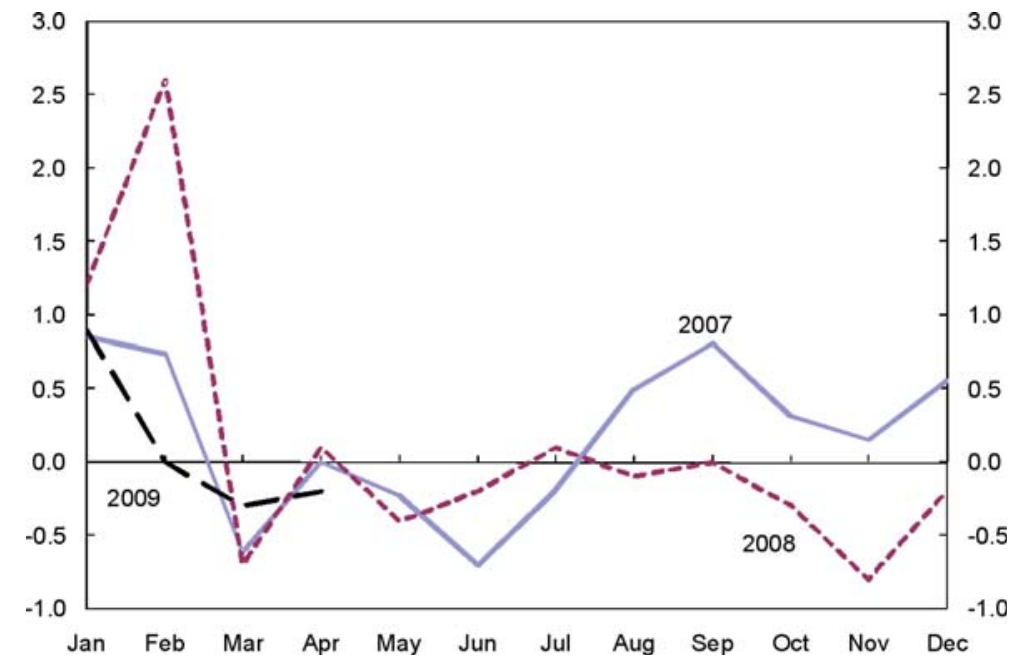

Source: Citi Investment Research and Analysis.

Inflationary pressures also are not significant. Some observers are probably paying too much attention to the inflation/reflation risk in the United States and China. Recent money growth could be expected eventually to lead to inflation. The current negative output gap is, however, a more powerful cap on price levels than the quantity of money, as continued deleveraging (and the lack of re-leveraging) has sharply reduced the velocity of money circulation. More importantly, after widespread criticism, the PBOC and the US Federal Reserve might be anxious to re-establish their credibility once signs of inflation emerge. The greater risk now therefore might still be for policymakers to act too quickly, which could hurt the momentum for recovery.

Normalising inflation should bring higher bond yields. Without excessive pricing pressures in either direction, the negative base effect for the CPI will ease significantly by August. This could bring the year-onyear CPI rate to 2 per cent. Under this scenario, bond yields will probably rise (Figure 7.9). The flush liquidity conditions now could delay this rebound in yields, but not for long. 
Figure 7.9 CPI and bond yields (per cent year-on-year)

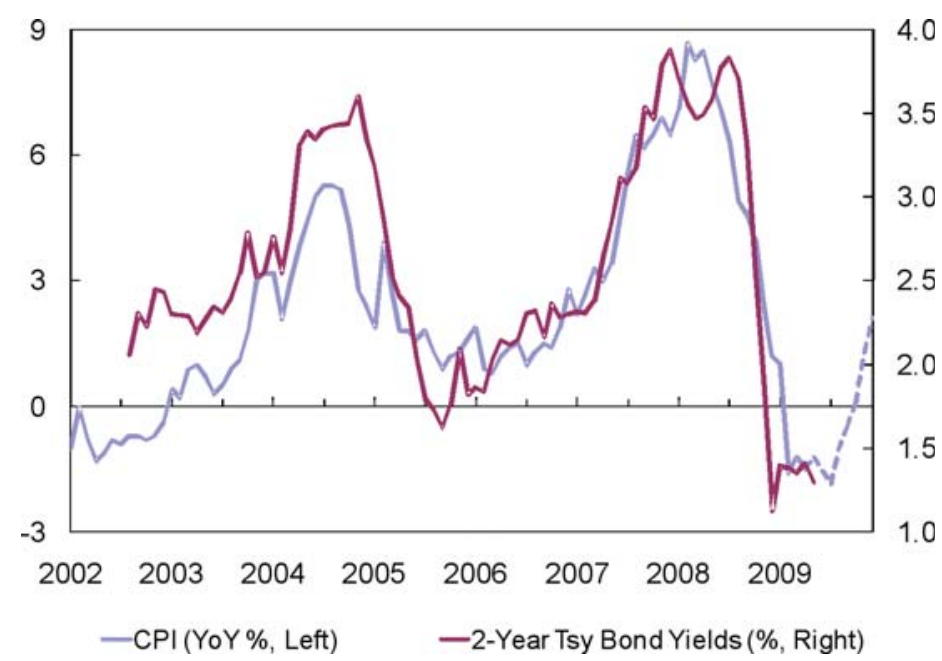

Source: People's Bank of China.

The turning point for the producer price index (PPI) could also be near. Commodity prices rebounded smartly in May, with the CRB industrial prices index up 7 per cent and crude prices up 15 per cent. The PMI for input prices turned the corner last December and rose above 50 in April, which has probably continued in May. Because PPI inflation peaked in July-August 2008 at about 10 per cent year-on-year, the base effect would keep PPI negative until the fourth quarter.

Against this backdrop, monetary policy has room to stay loose. Officials have sworn to keep monetary policy loose, maintaining that an asset bubble now is more tolerable than not having sufficient liquidity. Credit expansion could stay at a fast pace as well, probably with about RMB300 billion in new loans each month. The current rate of RMB500-600 billion, however, is still too aggressive, producing credit growth in excess of 30 per cent year-on-year.

The first wave of commercial bills issued after the crash is approaching expiration, which could create some refinancing needs (Figure 7.10). This will not be a big problem, but could create bigger new loans, while outstanding amounts rise more slowly. Those looking to earn a safe interest spread might find this more difficult, as some banks have reduced their deposit rates voluntarily due to excess liquidity. 
Figure 7.10 New loans (RMB billion)

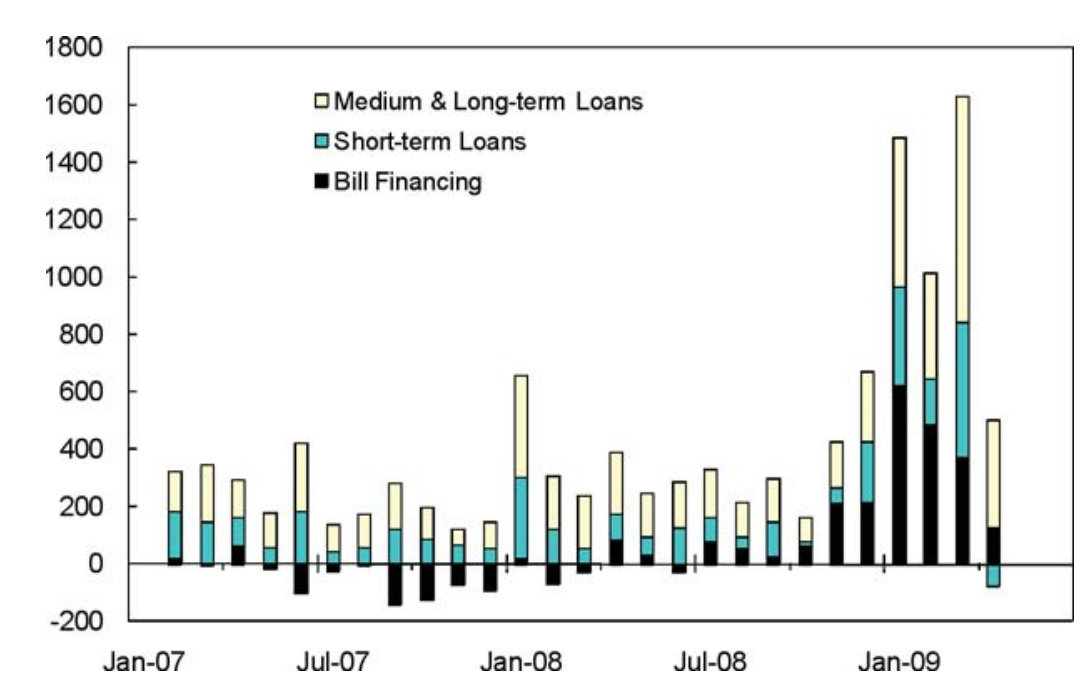

Source: People's Bank of China.

Policymakers will probably protect the recovery with ample liquidity and the ever-ready next round of stimulus, but there will probably be little action in the near term. Recent statements from officials have been mixed, recognising the progress made so far and raising concerns about loan quality and an excessive rebound in property prices. Some local governments have resumed policies to limit property speculation. The credit expansion will probably continue to slow, but will remain at a historically rapid pace.

\section{Sustainability of rapid growth}

The rebound in economic activity gives rise to the hope that not only will China come out of recession first, it will lead the world along the path of recovery. A critical question remains, however, about the sustainability of China's rapid growth. The recovery in growth is mainly the result of government policy — but has the government made the best policy choices?

The most direct consequence of the financial crisis is the collapse of China's exports. This probably provided a golden opportunity for China to rebalance its growth pattern, especially by reducing its dependency on external markets. The Chinese Government made its best effort to offset the loss of this source of growth by boosting domestic investment. 
This government-sponsored growth recovery, however, creates a set of new issues. As investment surged sharply, domestic demand became even more unbalanced. The rush to plan and implement investment projects also raises questions about efficiency and investment returns. More importantly, the stimulus policies strengthened the state sector significantly while weakening the relative position of private enterprises.

Some policymakers argue that investment inefficiency should be tolerated, as the stimulus policies are temporary crisis-fighting measures. The government will, however, have to deal with the aftermath of the financial crisis and the stimulus packages. Some observers are perhaps hoping that the export market will return once the global economy recovers.

The truth, however, is that despite the expected recovery of the US economy in the coming years, American households might increase their saving ratios. This means that growth in US consumption and Chinese exports is likely to be weaker in the future than before the crisis. Chinese growth will therefore have to rely increasingly on domestic demand going forward.

Unfortunately, there is a significant risk with the current momentum of domestic demand. The extraordinary credit expansion seen in the first quarter of 2009 has already slowed significantly in recent months and is likely to moderate further. The dramatic growth in state investment crowded out private sector activities. The majority of new loans, for instance, went to the state sector. Abundant liquidity has already started to push up asset prices around the country, especially in the property sector. While improvement in property market sentiment should be welcomed, as it could help to stabilise investment and other economic activities, the premature creation of a property bubble could be costly later.

According to policymakers, the purpose of the government's stimulus policy is to support growth. The purpose of maintaining strong growth is to create enough jobs; and the purpose of job creation is to maintain social stability. Boosting state investment is, however, probably not an efficient way of ensuring social stability. China is probably able to support strong growth in the near term, but state investment-led growth might not create enough jobs to offset job losses in the export sector. If that is the case, social stability could still be at risk despite strong growth. 
The more efficient way of achieving social stability in a time of crisis is to provide direct welfare and income support to households. According to surveys by $\mathrm{PBOC}$ officials, the costs of keeping factories in production are often four times the cost of providing direct support to households.

More importantly, sustainability of rapid growth in the long run depends on a more rapid rise in consumption. To boost consumption, the government will need to improve the social welfare system as well as changing income distribution among the government, enterprises and households.

Therefore, for short-term and long-term growth and stability purposes, it should be much more effective for the government to spend resources on boosting consumption rather than on stimulating state investment. If the government doesn't do it now, it will have to do it after 2010. Unfortunately, conditions will be much less favourable by then as the non-performing loans of the banking sector will be much bigger, fiscal conditions will be much weaker and debt burdens much higher. 